\title{
CuAl LDH/Rice Husk Biochar Composite for Enhanced Adsorptive Removal of Cationic Dye from Aqueous Solution
}

\author{
Neza Rahayu Palapa1, Tarmizi Taher ${ }^{2}$, Bakri Rio Rahayu ${ }^{1}$, Risfidian Mohadi ${ }^{3}$, Addy \\ Rachmat $^{3}$, Aldes Lesbani ${ }^{1, *}$
}

\begin{abstract}
${ }^{1}$ Graduate School of Mathematics and Natural Science Graduate School, Universitas Sriwijaya, Jl. Padang Selasa, No. 524 Ilir Barat 1, Palembang, South Sumatra, Indonesia.

2Institute of Regional Innovation, Hirosaki University, Matsubara 2-1-3, 030-0813, Aomori City, Aomori, Japan.

${ }^{3}$ Department of Chemistry, Faculty of Mathematics and Natural Sciences, Universitas Sriwijaya, Jl. Palembang-Prabumulih, Km. 32, Ogan Ilir, South Sumatra, Indonesia.
\end{abstract}

Received: 17th May 2020; Revised: 14 th June 2020; Accepted: 14th June 2020; Available online: 30th July 2020; Published regularly: August 2020

\begin{abstract}
The preparation of $\mathrm{CuAl} \mathrm{LDH}$ and biochar (BC) composite derived from rice husk and its application as a low-cost adsorbent for enhanced adsorptive removal of malachite green has been studied. The composite was prepared by a one-step coprecipitation method and characterized by X-ray Diffraction (XRD), Fourier Transform Infra Red (FTIR), Brunauer-Emmett-Teller (BET), and Scanning Electron Microscopy - Energy Dispersive X-ray (SEM-EDX). The result indicated that $\mathrm{CuAl}$ LDH was successfully incorporated with the biochar that evidenced by the broadening of XRD peak at $2 \theta=24^{\circ}$ and the appearance of a new peak at $1095 \mathrm{~cm}^{-1} \mathrm{on}$ the FTIR spectra. The BET surface area analysis revealed that CuAl/BC composite exhibited a larger surface area $\left(200.9 \mathrm{~m}^{2} / \mathrm{g}\right)$ that the original $\mathrm{CuAl} \mathrm{LDH}\left(46.2 \mathrm{~m}^{2} / \mathrm{g}\right)$. Surface morphological changes also confirmed by SEM image, which showed more aggregated particles. The result of the adsorption study indicated the composite material was efficient in removing malachite green with Langmuir maximum adsorption capacity of $\mathrm{CuAl} / \mathrm{BC}$ reaching $470.96 \mathrm{mg} / \mathrm{g}$, which is higher than the original $\mathrm{CuAl} \mathrm{LDH} 59.523 \mathrm{mg} / \mathrm{g}$. The thermodynamic analysis suggested that the adsorption of malachite green occurs spontaneously $(\Delta G<0$ at all tested temperature) and endothermic nature. Moreover, the $\mathrm{CuAl} / \mathrm{BC}$ composite showed strong potential as a low cost adsorbent for cationic dye removal since it showed not only a high adsorption capacity but also good reusability. Copyright (C) 2020 BCREC Group. All rights reserved
\end{abstract}

Keywords: Adsorption; Biochar; Composite Material; Layered Double Hydroxide; Malachite Green

How to Cite: Palapa, N.R., Taher, T., Rahayu, B.R., Mohadi, R., Rachmat, A., Lesbani, A. (2020). CuAl LDH/Rice Husk Biochar Composite for Enhanced Adsorptive Removal of Cationic Dye from Aqueous Solution. Bulletin of Chemical Reaction Engineering \& Catalysis, 15(2), 525-537 (doi:10.9767/bcrec.15.2.7828.525-537)

Permalink/DOI: https://doi.org/10.9767/bcrec.15.2.7828.525-537

\section{Introduction}

Layered double hydroxide $(\mathrm{LDH})$ is a synthetic anionic clays mineral having the general

* Corresponding Author.

E-mail: aldeslesbani@pps.unsri.ac.id (A. Lesbani) formula $\left[\mathrm{M}^{+2_{1-\mathrm{x}}} \mathrm{M}^{+3} \mathrm{x}(\mathrm{OH})_{2}\right]_{\mathrm{x}} \mathrm{A}_{\mathrm{x} / \mathrm{n}^{-\mathrm{n}}} \cdot \mathrm{mH}_{2} \mathrm{O}$ [1]. $\mathrm{M}^{2+}$ and $\mathrm{M}^{3+}$ represent divalent and trivalent metal cation. The stacked of positive layers separated by interlamellar space consists of anions and water molecules [2-3]. Anions within the space act as counterbalancing and exchangeable species denote by $\mathrm{A}^{-\mathrm{n}}$, such as nitrate [4], carbonate, 
sulfate [5], organic acid anions [6] and also inorganic anions [7-8]. LDH shows great potentials in various applications such as adsorption, membrane separation, catalysis, electrochemistry, and biomedicine [9-12].

The LDH advantages include high adsorption capacity, easy to prepare, extensive specific surface area, high flexibility, and excellent thermal stability [13]. The layers of LDH however, can be exfoliated during application hence cannot be reused [14]. Structure improvement therefore is needed particularly for adsorbent application by introducing supporting material, which improves the integrity of layers. Biochar i.e. an activated carbon made from biomass has been reported can be used in dyes removal [15]. Biochar is a pyrogenic black carbon that has been used as a carbon fixer in soil improvement and recently incorporated as supporting for increasing surface area of material [16]. BC has a high adsorption capacity, and a large surface area [17].

Advanced utilization of biochar on materials structure improvement was reported in $\mathrm{LDH}$ composite. The resulting composite used in removing contaminants within wastewater through the adsorption method [18-19]. Wan et al. [20] reported that phosphate successfully adsorbed by using $\mathrm{Mg}-\mathrm{Al}$ and $\mathrm{Mg}-\mathrm{Fe}$ bamboo BC. The adsorption achieved $>95 \%$ phosphate removal within an hour [20]. Previously, Wang et al. [21] reported that arsenic adsorption using $\mathrm{Ni}-\mathrm{Fe}$ pine $\mathrm{BC}$ composite has a maximum adsorption capacity $1.56 \mathrm{~g} / \mathrm{kg}$ and $4.38 \mathrm{~g} / \mathrm{kg}$, respectively [21]. Meili et al. [19] reported the preparation of bone $\mathrm{BC}$ supported on $\mathrm{Mg}-\mathrm{Al}$ $\mathrm{LDH}$ and used it on the removal of methylene blue. The maximum adsorption capacity attains $406 \mathrm{mg} / \mathrm{g}$ at $40{ }^{\circ} \mathrm{C}$ [19]. According to research, the presence of other supporting materials as composite $\mathrm{LDH} / \mathrm{BC}$ gives the effect prevents agglomeration and improves the stability and some properties of the materials such as high performance adsorptive, sustainable and economical adsorbent materials [22]. Thus, $\mathrm{LDH} / \mathrm{BC}$ has the potential to generate useful adsorbents with inherent and remarkable exchangeability of anion, high surface area, and less toxicity for organic contaminated wastewater treatment.

In the present work, we aimed to study the adsorption of malachite green using $\mathrm{CuAl}$ rice husk BC composite in aqueous solution. However, to the best of our knowledge, there is no report $\mathrm{CuAl} \mathrm{LDH}$ composite to rice husk biochar as a removal agent of malachite green. The effect of various conditions including $\mathrm{pH}$, time, initial concentration, temperature ad- sorption and reusability adsorbent effectivity were investigated in batch adsorption apparatus. Kinetic, isotherm, and thermodynamic adsorption of malachite green on composite material was discussed in this article.

\section{Materials and Methods}

\subsection{Materials}

The materials used in the experiment were copper nitrate trihydrate $\left(\mathrm{Cu}\left(\mathrm{NO}_{3}\right)_{2} .3 \mathrm{H}_{2} \mathrm{O}\right)$ (by Merck), aluminum nitrate nonahydrate $\left(\mathrm{Al}\left(\mathrm{NO}_{3}\right)_{3} .9 \mathrm{H}_{2} \mathrm{O}\right)$ (by Merck), sodium hydroxide $(\mathrm{NaOH})$ (by Sigma Aldrich) and malachite green (by Merck). All those chemicals were proanalysis grade. The rice husk biochar source was purchased from Bukata Organic Indonesia.

\subsection{Preparation of $\mathrm{CuAl} / \mathrm{BC}$ Composite}

The $\mathrm{CuAl} / \mathrm{BC}$ composite was prepared by developing our previously reported work [23]. $\mathrm{CuAl} / \mathrm{BC}$ composite was prepared by coprecipitation method as follow: $10 \mathrm{~mL}$ of $0.75 \mathrm{M}$ copper nitrate and $10 \mathrm{~mL}$ of $0.25 \mathrm{M}$ aluminum nitrate (3:1) were mixed under vigorous stirring for an hour until the complete dissolution of the starting materials. The resulting mixtures were transferred to another beaker containing $1 \mathrm{~g}$ of the biochar under continuous stirring. As much as $4 \mathrm{M}$ sodium hydroxide solution was added dropwise until the settlement formed at $\mathrm{pH}$ 10. The mixing solution was kept at $80{ }^{\circ} \mathrm{C}$ for three days. Composites were washed and dried at $40^{\circ} \mathrm{C}$ for a day.

\subsection{Material Characterization}

X-ray diffraction pattern of the prepared adsorbent was recorded using XRD Rigaku Miniflex-600. The sample scanned at scan speed $1 \%$ min from $2 \theta$ range $5-70^{\circ}$. Specific surface area was calculated by using Multipoint BET method based on data collected by ASAP Micromeritics 2020 at $77 \mathrm{~K}$. Infrared spectra obtained from FTIR Shimadzu Prestige-21 that measured by $\mathrm{KBr}$ disc method and scanned at wavenumber range of $400-4000 \mathrm{~cm}^{-1}$. The surface morphology of materials was characterized using SEM Quanta-650 Oxford instrument. The concentration of dye was analyzed using UV-Visible spectrophotometer Bio-Base BKUV1800 at wavelength $619 \mathrm{~nm}$.

\subsection{Adsorption Study}

The adsorption study was carried out using a batch system. The $\mathrm{pH}$ effect, the equilibrium 
time through the kinetics experiments, and the influence of temperature and concentration on the adsorption isotherm were investigated.

The effect of $\mathrm{pH}$ was investigated by adjusting $\mathrm{pH} 3$ to 11 in the following procedure: 0.05 $\mathrm{L}$ of $25 \mathrm{mg} / \mathrm{L}$ malachite green solution with adjusted $\mathrm{pH}$ was placed in an Erlenmeyer. A 0.05 $\mathrm{g}$ of $\mathrm{CuAl} / \mathrm{BC}$ composite was added into Erlenmeyer. The solution was shaken at $120 \mathrm{rpm}$ by horizontal shaker at room temperature for two hours. After this time, the solution was centrifuged, and the concentration of malachite green determined by UV-Visible spectrophotometer at wavelength $619 \mathrm{~nm}$.

The kinetic study was carried out by mixing $0.05 \mathrm{~g}$ of composite adsorbent with $0.05 \mathrm{~L}$ malachite green solution at $\mathrm{pH} 9$ and room temperature in different initial concentrations. The kinetic parameters evaluated based on pseudofirst-order (PFO) and pseudo-second-order (PSO) approaches. The equation is written as follows Equations (1) and (2):

$$
\begin{aligned}
& \log \left(q_{e}-q_{t}\right)=\log q_{e}-\left(\frac{k_{1}}{2.303}\right) t \\
& \frac{t}{q_{t}}=\frac{1}{k_{2} q_{e}^{2}}+\frac{1}{q_{e}} t
\end{aligned}
$$

Note: $q_{e}$ is adsorption capacity at equilibrium $(\mathrm{mg} / \mathrm{g}) ; q_{t}$ is adsorption capacity at $t(\mathrm{mg} / \mathrm{g}) ; t$ is adsorption time (min); $k_{1}$ is adsorption kinetic rate at pseudo-first-order $\left(\mathrm{min}^{-1}\right)$ and $k_{2}$ is adsorption kinetic rate at pseudo second-order (g/mg.min).

The isotherm and thermodynamic study were investigated by similar procedure as kinetic study. $0.05 \mathrm{~g}$ of composite adsorbent was

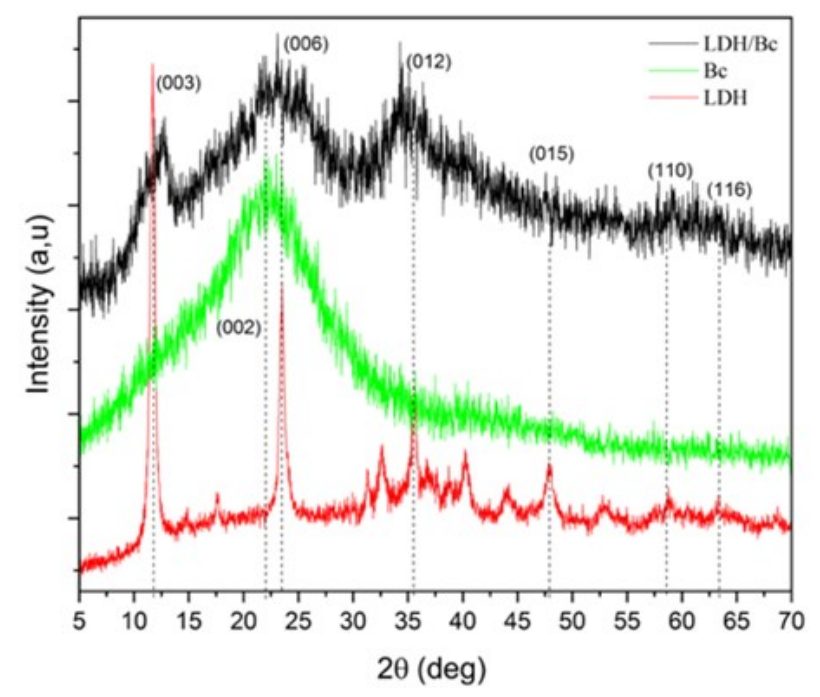

Figure 1. X-ray powder patterns of $\mathrm{CuAl} \mathrm{LDH}$, $\mathrm{BC}$ and $\mathrm{CuAl} / \mathrm{BC}$ composite. mixed with $0.05 \mathrm{~L}$ malachite green solution at $\mathrm{pH} 9$ in various temperatures and initial concentrations. The Langmuir isotherm models represented as the Equation (3) and Freundlich isotherm model written as Equation (4):

$$
\begin{aligned}
& \frac{C}{m}=\frac{1}{q_{m} b}+\frac{C}{b} \\
& \ln q_{e}=\ln k_{F}+\left(\frac{1}{n}\right) \ln C_{e}
\end{aligned}
$$

where $C$ is a saturated concentration of adsorbate; $m$ is the amount of adsorbate; $q_{m}$ is the maximum adsorption capacity $(\mathrm{mg} / \mathrm{g}), b$ is the Langmuir constant $(\mathrm{L} / \mathrm{mg}), k_{F}$ is Freundlich constant and $n$ is Freundlich linear constant.

\subsection{Reusability Study}

The reusability test was aimed to investigate the durability of composite after long period of application. In this study, several reagents such as ethylenediaminetetraacetic acid, sodium chloride, water, sodium hydroxide, hydrochloride acid were used on the desorption process. Reusability evaluation carried out by mixing $0.05 \mathrm{~g}$ of composite adsorbent in $0.05 \mathrm{~L}$ malachite green $100 \mathrm{mg} / \mathrm{L}$. The mixture was shaken for two hours, followed by filtration to separate the adsorbent from adsorbate. The adsorbent dried in oven while the adsorbate had its absorbance read. The dried adsorbent (CuAl/BC-MG LDH) reused by adding it in $0.025 \mathrm{~L}$ of $\mathrm{HCl}(0.01 \mathrm{M})$ follow by stirring for two hours and then dried in an oven. The dried material used in another adsorption test in a similar procedure, in which this procedure repeated three cycles of operations.

\section{Results and Discussions}

\subsection{Adsorbent Characterization}

The diffractogram of $\mathrm{BC}, \mathrm{CuAl} \mathrm{LDH}$, and $\mathrm{CuAl} / \mathrm{BC}$ composite was shown in Figure 1. The diffractogram $\mathrm{CuAl} / \mathrm{BC}$ resembles the characteristic diffraction pattern of $\mathrm{CuAl} \mathrm{LDH}$ and biochar. The intense peaks of CuAl LDH (JCPDS No. 37-0630) showed the peaks at $11.8^{\circ}, 26.3^{\circ}$, $35.8^{\circ}, 47.8^{\circ}, 58.9^{\circ}$, and $63.1^{\circ}$ corresponding to reflections of (003), (006), (012), (015), (110), and (116) which indicated the materials have layer structure [23]. Similar findings from $\mathrm{CuAl} \mathrm{LDH}$ also exhibited in XRD pattern of $\mathrm{CuAl} / \mathrm{BC}$ composite, although the intensity of $\mathrm{LDH}$ characteristic was decreased due to amorphous of biochar which would be enhancing the hydrophobic nature of the composite material [24]. The broad peak at $24^{\circ}$ corresponding to 
reflections (002) on the surface of the $\mathrm{LDH}$ due to the presence of biochar.

The FTIR spectra of biochar, LDH and composite presented in Figure 2. The characteristic band at $3448 \mathrm{~cm}^{-1}$ and $1635 \mathrm{~cm}^{-1}$ attributed to $\mathrm{OH}$ stretching vibrations and bending vibrations of the hydroxyl groups from water molecules. The band at $1000 \mathrm{~cm}^{-1}$ belongs to the vibration of metal-oxygen. The bending vibration of nitrate appears at $1381 \mathrm{~cm}^{-1}$ both on LDH pristine and composite. The absorption band at $1095 \mathrm{~cm}^{-1}$ denotes the stretching vibration of $\mathrm{C}-\mathrm{O}$. The presence of these various absorption bands confirms the successful preparation of the composite $\mathrm{LDH} / \mathrm{BC}$.

The textural properties determination carried out by using $\mathrm{N}_{2}$ adsorption-desorption method and the result presented in Table 1 while the adsorption isotherm shown in Figure

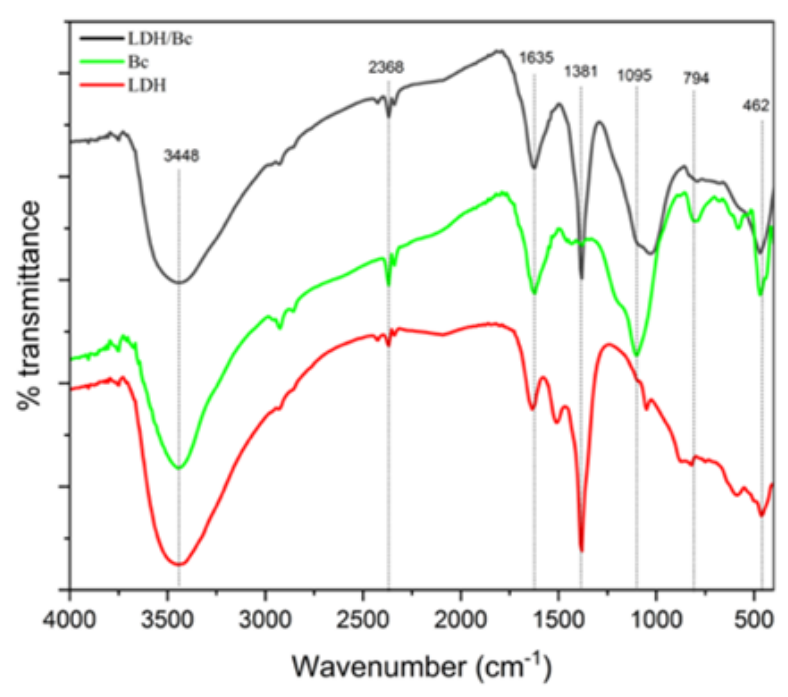

Figure 2. FTIR spectrum of $\mathrm{CuAl} \mathrm{LDH}, \mathrm{BC}$ and $\mathrm{CuAl} / \mathrm{BC}$ composite.

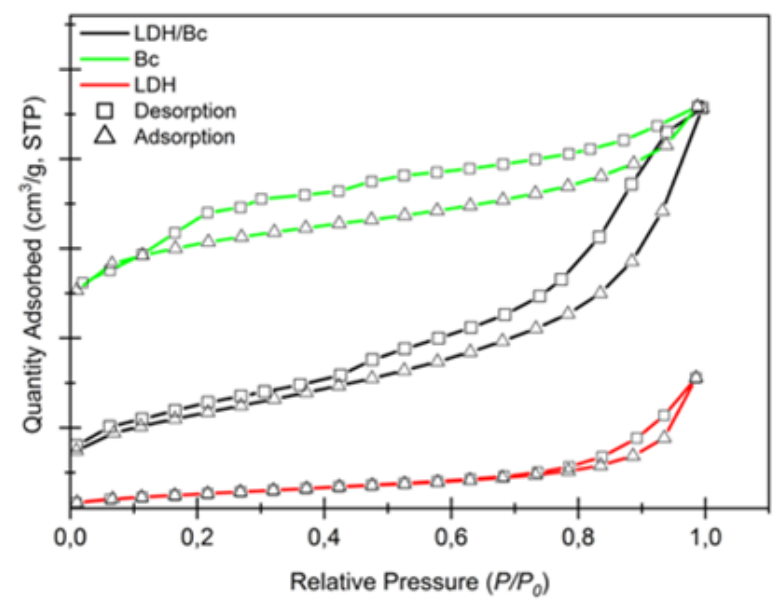

Figure 3. $\mathrm{N}_{2}$ adsorption-desorption profile of $\mathrm{CuAl} \mathrm{LDH}, \mathrm{BC}$ and $\mathrm{CuAl} / \mathrm{BC}$ composite.
3. The value of BET surface area, pore size and pore volume listed in Table 1 shows that the increase of the surface area of $\mathrm{LDH}$ after supported by $\mathrm{BC}$ along with the decreases in pore size. The adsorption isotherms of each material shown in Figure 3. The isotherm curve showed type IV with a typical hysteresis loop, which is associated with capillary condensation within mesopore [25]. The hysteresis curve of these materials resemble to type H3. The H3 type hysteresis loop, according to IUPAC classification resulted from slit-shaped pores produced by aggregates of plate-like particles [26].

The $\mathrm{CuAl} / \mathrm{BC}$ composite resulted from this experiment shows a remarkable surface area according to BET calculation $\left(200.9 \mathrm{~m}^{2} / \mathrm{g}\right)$. Although the pore size of composite lower than initial LDH, its pore volume increases three times. The decrease in pore size probably due to the insertion of biochar particles within layers of LDH. Figure 4 suggests that biochar distributed on the surface of $\mathrm{CuAl} \mathrm{LDH}$, which confirms by Table 1 , causes an increase in the surface area, and the occupation of the pores. The EDS supports the data as shown on Figure $4 \mathrm{~d}$. The pristine $\mathrm{LDH}$ of $\mathrm{CuAl}$ shows the composition of $\mathrm{Cu}$ and $\mathrm{Al}$, i.e. $46 \%$ and $6 \%$, respectively. Figure $4 \mathrm{f}$. shows that composite consists of $\mathrm{Cu}, \mathrm{Al}, \mathrm{C}, \mathrm{O}, \mathrm{Si}$ at $35 \%, 5.1 \%, 11.2 \%, 39 \%$, and $7.7 \%$, respectively.

According to the previous report, the morphology of $\mathrm{CuAl} \mathrm{LDH}$ pristine shows surface heterogeneity with large aggregate on its surface [23]. The LDH composite biochar exhibited a similar result reported by Wang et al. [27], which is the surface morphology of biochar modified LDH has no particular structure and predominantly reveals the presence of $\mathrm{LDH}$ phase.

Figure 5 shows the particle size distribution of $\mathrm{CuAl} / \mathrm{BC}$ composite was obtained from ImageJ application 1.52q. The sample of $\mathrm{CuAl} / \mathrm{BC}$ composite comprises of aggregates with the size of particles distributed from $9.09 \mu \mathrm{m}$ to 54 $\mu \mathrm{m}$. According to Sun et al. [28] the agglomeration of $\mathrm{LDH}$ particles causes the increase of

Table 1. BET surface area, BJH pore size and pore volume of the prepared materials.

\begin{tabular}{lccc}
\hline Materials & $\begin{array}{c}\text { BET } \\
\text { Surface } \\
\left(\mathrm{m}^{2} / \mathrm{g}\right)\end{array}$ & $\begin{array}{c}\text { Pore Size } \\
(\mathrm{nm})\end{array}$ & $\begin{array}{c}\text { Pore } \\
\text { Volume } \\
\left(\mathrm{cm}^{3} / \mathrm{g}\right)\end{array}$ \\
\hline Biochar & 72.25 & 3.33 & 0.060 \\
$\mathrm{CuAl}$ & 46.2 & 10.39 & 0.116 \\
$\mathrm{CuAl} / \mathrm{BC}$ & 200.90 & 7.03 & 0.350 \\
\hline
\end{tabular}


particle size. The agglomeration can affect the particle size is a micro-scale magnitude [29]. On the other hand, the particle size of material results from varying $\mathrm{pH}$ and temperature during the synthesis process in the aqueous phase [30-31]. The average particle size of $\mathrm{CuAl} / \mathrm{BC}$ composite is $28 \mu \mathrm{m}$.

\subsection{Effect of $\mathrm{pH}$}

Figure 6 shows the effect of $\mathrm{pH}$ on the adsorption of malachite green by using $\mathrm{CuAl} \mathrm{LDH}$ and $\mathrm{CuAl} / \mathrm{BC}$ composite. The effective $\mathrm{pH}$ adsorption achieved at $\mathrm{pH}$ 9. The $\mathrm{pH}_{\mathrm{pzc}}$ of $\mathrm{CuAl}$ $\mathrm{LDH}$ is 8 and $\mathrm{CuAl} / \mathrm{BC}$ composite is 6.8 , at $\mathrm{pH}_{\mathrm{pzc}}$ the interaction between adsorbents and MG molecule is minimal due to absence of electrostatic forces. Thus, the high adsorption capacity at $\mathrm{pH} 9$ possibly because the surface of these materials has a negative charge; hence the malachite green more likely to be absorbed. According to Parida \& Mohapatra [32], at $\mathrm{pH}>$ pzc, the negative charge of surface material affects the interaction between positively molecule and surface become favored. An increase in $\mathrm{pH}$ makes malachite green removal occurred rapidly until $\mathrm{pH}$ at 9 and cationic dye occupied on the active site of the surface. At acidic conditions, the removal of malachite green using $\mathrm{CuAl} / \mathrm{BC}$ composite and $\mathrm{CuAl}$ pristine achieved up to $40 \%$ removal if initial concentration was $25 \mathrm{mg} / \mathrm{L}$. At higher $\mathrm{pH}$ the removal of malachite green increased up to $>95 \%$ and $99 \%$ for composite materials. This achievement can be attributed to the surface charge and the availability of binding sites exist on the surface of the composite, a characteristic predominantly belongs to the LDH [33]. Furthermore, the $\mathrm{pH}$ of adsorption process greatly affected the interaction of adsorbent and adsorbate, so, the next
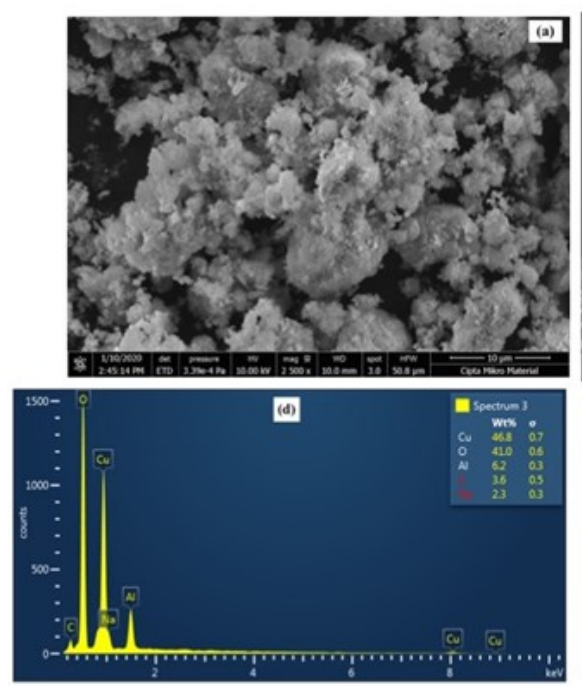
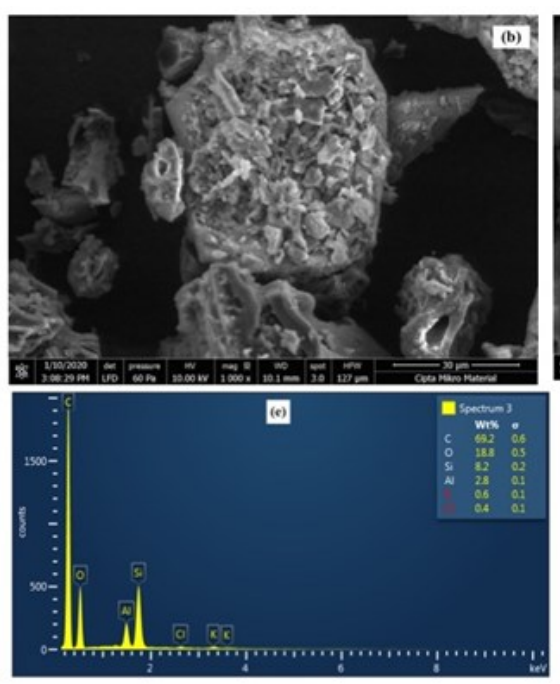
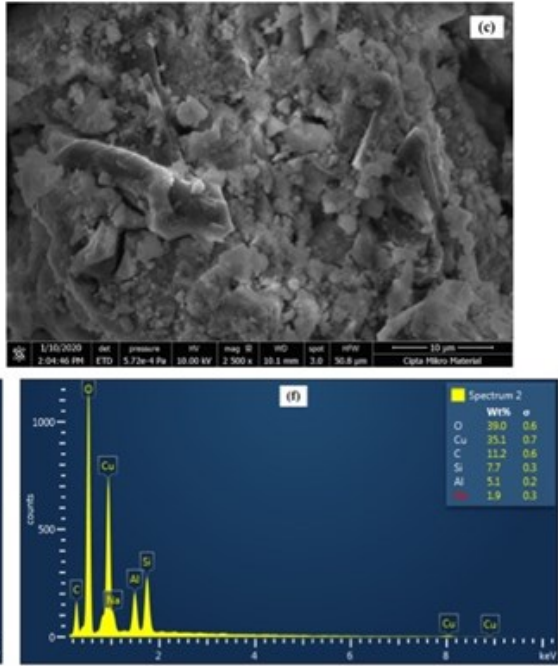

Figure 4. Morphologies and compositions of $\mathrm{CuAl} \mathrm{LDH}(\mathrm{a}, \mathrm{d}), \mathrm{BC}(\mathrm{b}, \mathrm{e})$ and $\mathrm{CuAl} / \mathrm{BC}$ composite (c,f).

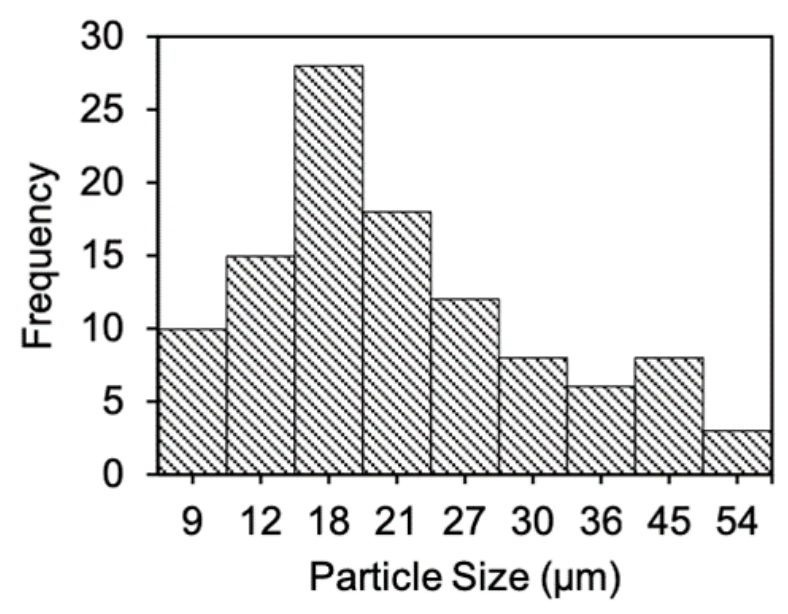

Figure 5. Distribution of particles size of $\mathrm{CuAl} / \mathrm{BC}$ composite.

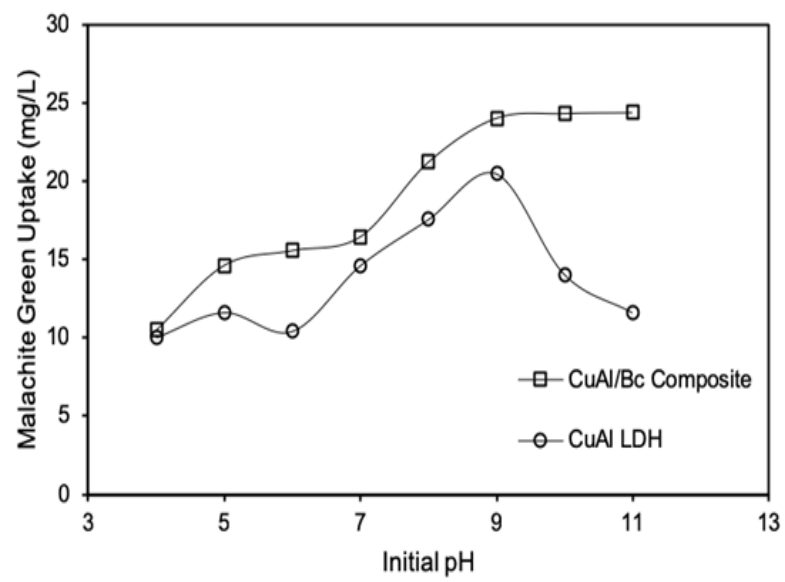

Figure 6. The effect of $\mathrm{pH}$ on adsorption of malachite green using $\mathrm{CuAl} / \mathrm{BC} \mathrm{LDH}$ and $\mathrm{LDH}$ pristine. 

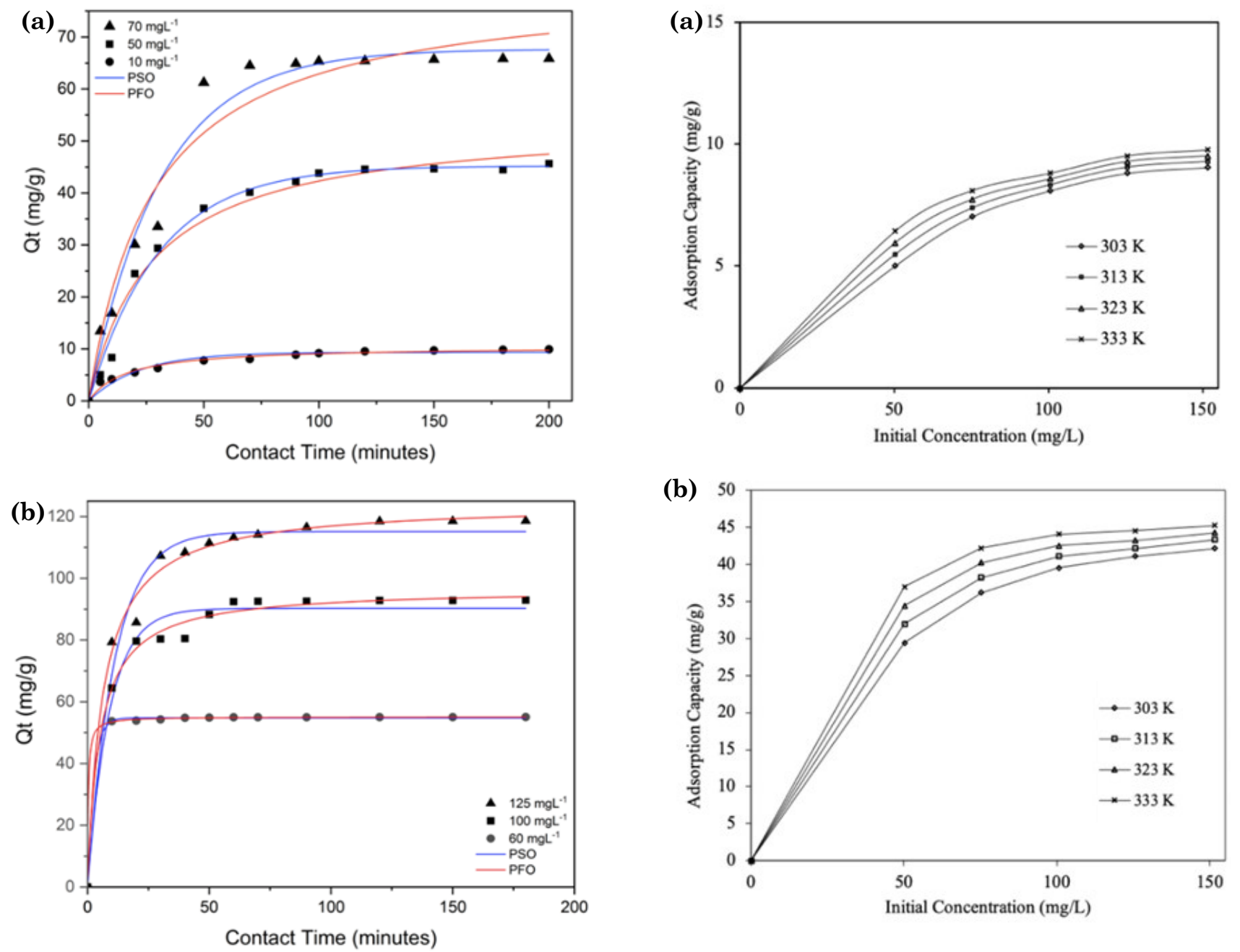

Figure 7. The effluent of contact time adsorption malachite green using (a) $\mathrm{CuAl}$ pristine and (b) $\mathrm{CuAl} / \mathrm{BC}$ composite.

Figure 8. Effect of adsorption temperature in several initial concentration of Malachite green by using (a) $\mathrm{CuAl}$ pristine and (b) $\mathrm{CuAl} / \mathrm{BC}$ composite.

Table 2. Kinetic parameters of $\mathrm{CuAl} \mathrm{LDH}$ and $\mathrm{CuAl} / \mathrm{BC}$ composite.

\begin{tabular}{|c|c|c|c|c|c|c|c|c|}
\hline \multirow[b]{2}{*}{ Adsorbent } & \multirow{2}{*}{$\begin{array}{c}\text { Initial } \\
\text { Concentration } \\
(\mathrm{mg} / \mathrm{L})\end{array}$} & \multirow[b]{2}{*}{$\begin{array}{c}\mathrm{Qe}_{\text {experiment }} \\
(\mathrm{mg} / \mathrm{g})\end{array}$} & \multicolumn{3}{|c|}{$\mathrm{PFO}$} & \multicolumn{3}{|c|}{ PSO } \\
\hline & & & $\begin{array}{l}\text { Qe Calc } \\
(\mathrm{mg} / \mathrm{g})\end{array}$ & $\mathrm{R}^{2}$ & $k_{1}$ & $\begin{array}{l}\text { QeCalc } \\
(\mathrm{mg} / \mathrm{g})\end{array}$ & $\mathrm{R}^{2}$ & $k_{2}$ \\
\hline \multirow{3}{*}{$\begin{array}{l}\mathrm{CuAl} / \mathrm{BC} \\
\text { composite }\end{array}$} & 60 & 34.476 & 31.69 & 0.975 & 0.038 & 34.246 & 0.999 & 0.119 \\
\hline & 100 & 58.081 & 36.165 & 0.949 & 0.033 & 59.428 & 0.998 & 0.001 \\
\hline & 125 & 74.125 & 53.801 & 0.967 & 0.048 & 76.124 & 0.998 & 0.001 \\
\hline \multirow{3}{*}{ CuAl-LDH } & 10 & 6.206 & 4.942 & 0.975 & 0.023 & 6.516 & 0.991 & 0.004 \\
\hline & 50 & 16.446 & 20.265 & 0.987 & 0.043 & 27.350 & 0.968 & 0.001 \\
\hline & 70 & 28.532 & 25.522 & 0.960 & 0.027 & 33.333 & 0.949 & 0.001 \\
\hline
\end{tabular}


experiments of adsorption were conducted at pH 9.

\subsection{Effect of Contact Time}

The kinetic parameters were determined by varying contact time. Figure 7 shows the effect of contact time on the dye adsorption for both $\mathrm{LDH}$ and composite. The result showed that $\mathrm{CuAl} / \mathrm{BC}$ composite adsorbed twice more dyes than $\mathrm{CuAl} \mathrm{LDH}$. This performance corresponded to the surface area of LDH composite, which is higher than pristine, as confirmed by BET analysis. Furthermore, Figure 7 informed that the adsorption equilibrium of malachite green reached after 90 minutes for LDH whereas the composite achieved at a shorter time i.e. 60 minutes. These results indicated that composite material showed a great potential adsorbent compare to pristine LDH. Pseudo first and second order (PFO and PSO) curves are shown in Figure 7 and the results of the kinetic parameter are presented in Table 2 .

Table 2 shows the kinetic parameter of malachite green adsorption obtained from the calculation by using Equations 1 and 2 based on experimental data. Both materials were best represented by PSO kinetic model rather than the PFO that having the calculated equilibrium capacity close to equilibrium capacity from experimental $\left(Q e_{\text {exp }}\right)$. The result acquired under the assumption that the difference between the concentration at the solid phase and equilibrium concentration might cause by the driving force. In this case, the adsorption by using composite observed experimentally faster than pristine LDH.

\subsection{Effect of Temperature and Isotherm Ad-} sorption

The adsorption isotherm of malachite green using $\mathrm{CuAl} \mathrm{LDH}$ and $\mathrm{CuAl} / \mathrm{BC}$ composite is shown in Figure 8. The increase in adsorption capacity can be related to the increase in temperature. The isotherm parameters were calculated by Langmuir and Freundlich isotherm model, as formulated by Equations (3) and (4). Table 3 presents the calculation results of the coefficient correlation, which identifies that the Langmuir model better fitted than the Freundlich model for composite material. A good fit of the Langmuir model indicates the adsorption process of the composite is monolayer with uniform energy distribution [34]. According to Meili et al. [19], the Langmuir process assumed that no significant interaction between adsorbate molecules. Thus, after dye particles occupied the active site, no further interaction occurs, particularly after the formation of monolayer [35].

Table 3 shows that the maximum adsorption capacity of $\mathrm{CuAl} / \mathrm{BC}$ composite significantly increased up to $470.96 \mathrm{mg} / \mathrm{g}$ at $50{ }^{\circ} \mathrm{C}$. The maximum adsorption capacity of $\mathrm{CuAl} / \mathrm{BC}$ is larger than $\mathrm{CuAl} \mathrm{LDH}$. Thus, $\mathrm{CuAl} / \mathrm{BC}$ composite displayed a high effectivity on malachite green adsorption. These findings confirm that composite material increases the dye adsorbed performance of $\mathrm{LDH}$ associated with the synergetic effect of biochar and $\mathrm{CuAl} \mathrm{LDH}$ in the composite due to the surface area of $\mathrm{CuAl} / \mathrm{BC}$ composite was bigger than pristine. The adsorption capacity increases with temperature. This tendency implies that adsorption occurs endothermically, particularly when involving

Table 3. Isotherm model of Malachite green adsorption using $\mathrm{CuAl}$ and $\mathrm{CuAl} / \mathrm{BC}$ composite.

\begin{tabular}{|c|c|c|c|c|c|c|}
\hline \multirow{2}{*}{ LDH } & \multirow{2}{*}{$\begin{array}{l}\text { Adsorption } \\
\text { Isotherm }\end{array}$} & \multirow{2}{*}{$\begin{array}{c}\text { Adsorption } \\
\text { Constant }\end{array}$} & \multicolumn{4}{|c|}{$T(\mathrm{~K})$} \\
\hline & & & 303 & 313 & 323 & 333 \\
\hline \multirow{6}{*}{$\mathrm{CuAl}$} & \multirow{3}{*}{ Langmuir } & $q_{\mathrm{m}}$ & 42.31 & 51.04 & 53.68 & 59.523 \\
\hline & & $B$ & 0.2191 & 0.314 & 0.44 & 0.2807 \\
\hline & & $R^{2}$ & 0.9815 & 0.997 & 0.996 & 0.998 \\
\hline & \multirow{3}{*}{ Freundlich } & $n$ & 3.35 & 4.056 & 3.47 & 4.87 \\
\hline & & $k_{\mathrm{F}}$ & 7.812 & 19.611 & 17.67 & 28.86 \\
\hline & & $R^{2}$ & 0.9099 & 0.98 & 0.99 & 0.984 \\
\hline \multirow{6}{*}{$\mathrm{CuAl} / \mathrm{BC}$} & \multirow{3}{*}{ Langmuir } & $q_{\mathrm{m}}$ & 467.92 & 465.33 & 468.19 & 470.96 \\
\hline & & $B$ & 0.085 & 0.0122 & 0.181 & 0.028 \\
\hline & & $R^{2}$ & 0.997 & 0.997 & 0.998 & 0.998 \\
\hline & \multirow{3}{*}{ Freundlich } & $n$ & 4.93 & 5.92 & 7.71 & 10.36 \\
\hline & & $k_{\mathrm{F}}$ & 15.79 & 20.11 & 24.61 & 29.34 \\
\hline & & $R^{2}$ & 0.946 & 0.950 & 0.944 & 0.937 \\
\hline
\end{tabular}


$\mathrm{LDH}$ adsorbent, as reported by some authors [36-37]. The several adsorbents for malachite green adsorption were conducted by researchers are presented in Table 4 . The adsorption capacity of the present work showed higher than reported by several authors. Hence, it can be concluded that the prepared $\mathrm{CuAl} / \mathrm{BC}$ exhibited great potential as an adsorbent for malachite green.

\subsection{Thermodynamic Study}

The thermodynamic parameter is an important aspect on the adsorption process. The

(a)

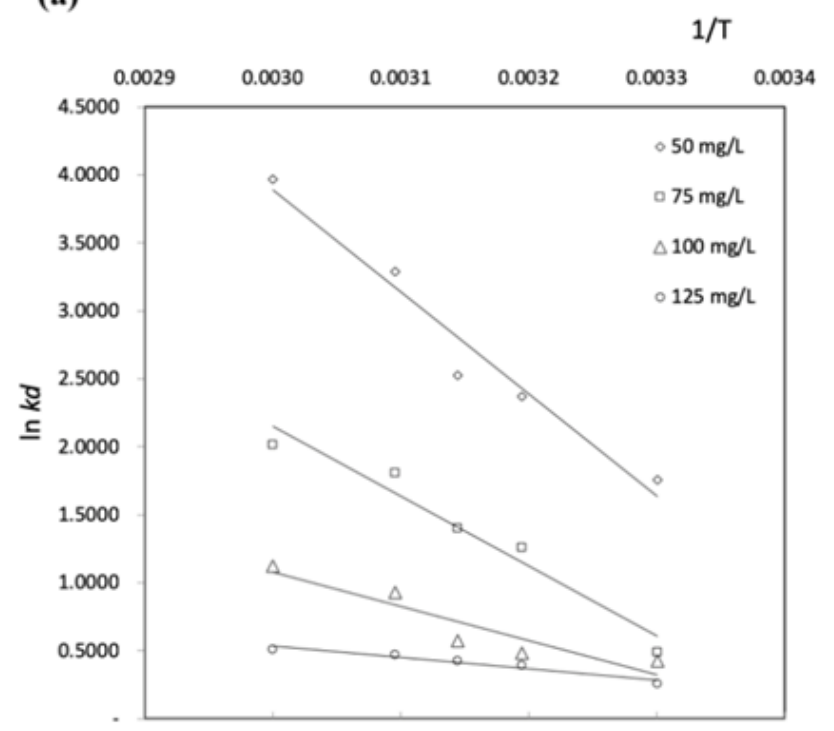

thermodynamic parameter evaluated according to the Van't Hoff equation. The equation is written as Equations (5) and (6):

$$
\begin{aligned}
& \Delta G=-R T \ln \left(K_{d}\right) \\
& \ln \left(K_{d}\right)=\frac{\Delta S}{R}-\frac{\Delta H}{R T}
\end{aligned}
$$

$R$ is constant gases, and $K_{d}$ is the adsorption distribution coefficient. The parameters determined by plotting Van't Hoff linear regression with $1 / T$ vs. $\ln \left(K_{d}\right)$. The linearity of adsorbents is shown in Figure 9.

Table 5 listed the value of the calculated thermodynamic parameters. The negative val-

(b)

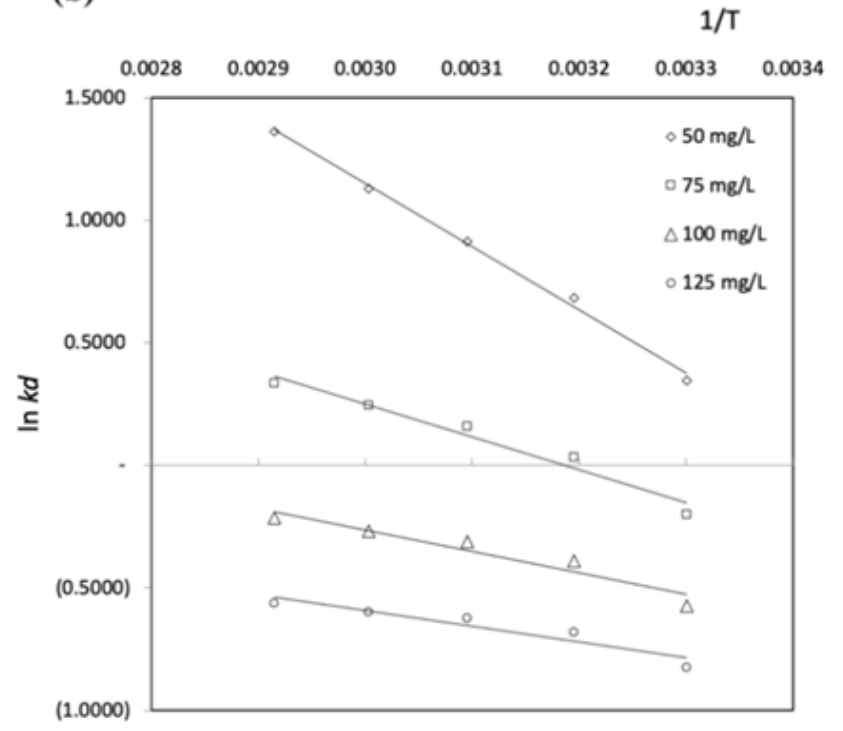

Figure 9. Van't Hoff linearity equation of malachite green adsorption using $\mathrm{CuAl}$ (a) and $\mathrm{CuAl} / \mathrm{BC}$ composite (b).

Table 4. The comparison of adsorption capacity of malachite green by various adsorbents.

\begin{tabular}{lccc}
\hline \multicolumn{1}{c}{ Adsorbent } & Adsorption Capacity $(\mathrm{mg} / \mathrm{g})$ & $\mathrm{pH}$ condition & Reference \\
\hline Rice Husk BC & 32.6 & 9 & {$[15]$} \\
NiAl LDH & 73.38 & - & {$[41]$} \\
Sugarcane BC & 10 & - & {$[42]$} \\
CuCr LDH & 59.2 & 9 & {$[23]$} \\
Carbon coat LDH composite & 126.58 & 6 & {$[36]$} \\
Clayey soil & 78 & 6 & {$[43]$} \\
Lime peel activated carbon & $47 \mathrm{mg} / \mathrm{g}$ & - & {$[44]$} \\
Manihot esculenta BC & 932.98 & 6.98 & {$[45]$} \\
Magnetic BC sewage sludge & 388 & 7 & {$[46]$} \\
Fe-modified BC & 172.3 & 6 & {$[47]$} \\
Ternary Mg/Al+Fe LDH & 999.4 & 4 & {$[48]$} \\
CuAl/BC composite & 470.96 & 9 & Present Work \\
CuAl LDH & 59.523 & 9 & Present Work \\
\hline
\end{tabular}


ue of $\Delta \mathrm{G}$ at various temperatures denotes the spontaneity adsorption process and it is more favorable in high temperatures. The positive value of $\Delta \mathrm{S}(30.702 \mathrm{~kJ} / \mathrm{mol}$ and $20.071 \mathrm{~kJ} / \mathrm{mol})$ of $\mathrm{MG}$ adsorption using pristine $\mathrm{CuAl} \mathrm{LDH}$ and composite corresponded to the randomness of solid-liquid phase interface during adsorption process [38]. $\Delta H$ the positive value indicated the reaction of adsorption become endothermic due to the MG adsorbed was increase with increasing temperature.

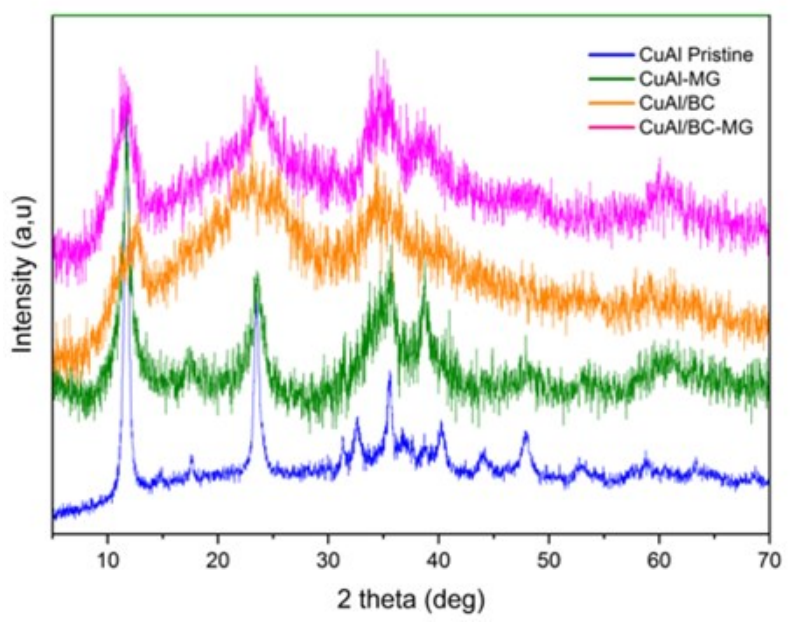

Figure 10. X-Ray diffraction powder of $\mathrm{CuAl}$ pristine, $\mathrm{CuAl}-\mathrm{MG}, \mathrm{CuAl} / \mathrm{BC}$ composite, and $\mathrm{CuAl} / \mathrm{BC}-\mathrm{MG}$.
3.6 Adsorption, Desorption, and Reusability Study

The solid structure of $\mathrm{LDH}$ and composite were evaluated by using X-Ray diffraction as shown in Figure 10. The diffractograms show similar pattern both $\mathrm{LDH}$ and composite before and after adsorption. The intensity in $2 \theta$ reflection (002) of $\mathrm{CuAl} / \mathrm{BC}$ composite decreases after the adsorption process, and the interlayer of $\mathrm{CuAl} / \mathrm{BC}$ composite slightly increases from 7.58 to $7.63 \AA$. This suggests the intercalation of malachite green within the $\mathrm{LDH}$ interlayer. According to Lu et al. [39], LDH interlayer after adsorption becomes smaller, but in this report, we obtain an increase in the interlayer distance as can be seen from peak shifting, which represents the (003). The enlargement of interlayer distance caused by malachite green intercalation within this layer [39].

In order to gain economic advantage as well as increase the effectiveness of potential adsorbent, the reusability study is necessary. The adsorbent reusability evaluation was carried out in several eluents on the desorption of malachite green from $\mathrm{CuAl}$ and $\mathrm{CuAl} / \mathrm{BC}$ composite. The results are shown in Figure 11. The higher percent of desorption in acid solution perhaps corresponds to the $\mathrm{LDH}$ charge becomes positive, so, the electrostatic attraction of adsorbent-dye molecule and $\mathrm{H}$-bond are weakened. Furthermore, in the base condition, the desorption is also higher because of hydro-
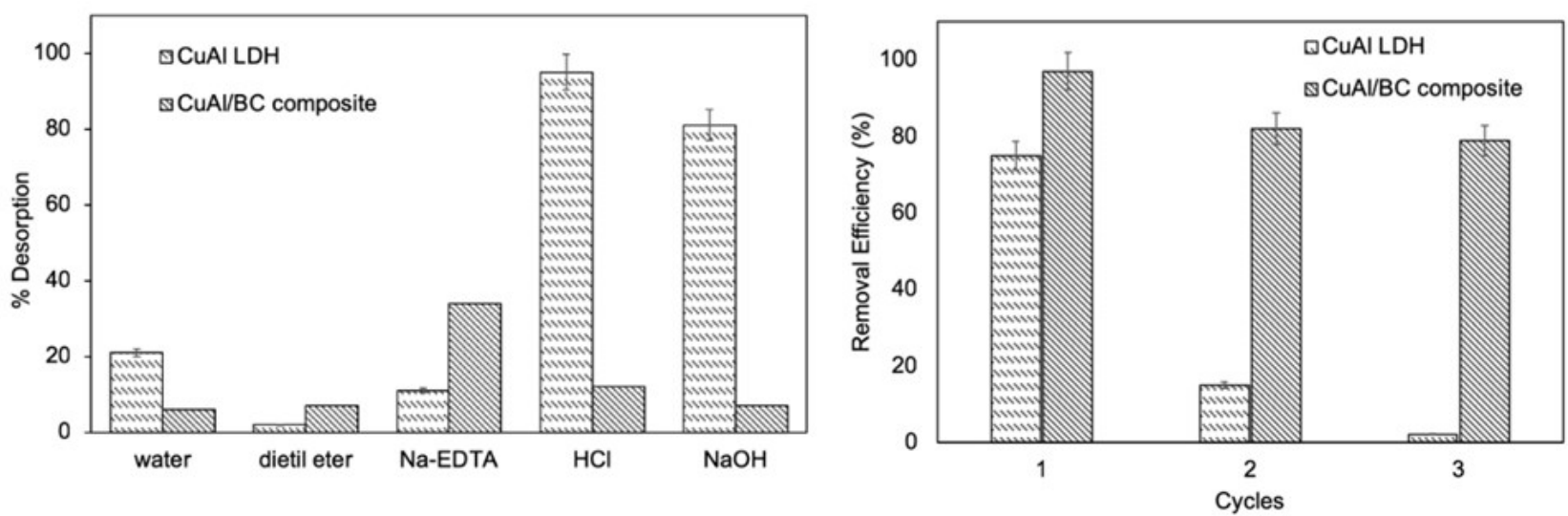

Figure 11. Desorption study by several eluent and reusability cycle of adsorbent.

Table 5. Thermodynamic parameters of $\mathrm{CuAl}$ and $\mathrm{CuAl} / \mathrm{BC}$ composite.

\begin{tabular}{lccccccc}
\hline \multirow{2}{*}{ Adsorbent } & \multicolumn{9}{c}{$\Delta G(\mathrm{~kJ} / \mathrm{mol})$} & \multirow{2}{*}{$\Delta S(\mathrm{~kJ} / \mathrm{mol})$} & $\Delta H(\mathrm{~kJ} / \mathrm{mol})$ \\
\cline { 2 - 5 } & $303 \mathrm{~K}$ & $313 \mathrm{~K}$ & $323 \mathrm{~K}$ & $333 \mathrm{~K}$ & & \\
\hline $\mathrm{CuAl}$ & -0.668 & -0.975 & -1.128 & -1.282 & 30.702 & 8.634 \\
$\mathrm{CuAl} / \mathrm{BC}$ & -0.194 & -0.495 & -0.646 & -0.796 & 20.071 & 7.912 \\
\hline
\end{tabular}


phobic interaction, and $\mathrm{OH}^{-}$ions are established to have a higher affinity for the anion exchange.

Figure 11 depicts that after three cycles of adsorption-desorption, the efficiency of dye removal decrease from $96 \%$ to $78 \%$ for the composite and $72 \%$ to $2 \%$ for $\mathrm{CuAl} \mathrm{LDH}$. $\mathrm{CuAl} \mathrm{LDH}$ dissolves in the acidic reagent hence not feasible to reuse. According to Nishimura et al. [40], $\mathrm{LDH}$ treated in regeneration processes might damage their structure due to exfoliation. However, the composite material prepared in this work can be reused, although the adsorption capacity slightly reduced.

\section{Conclusions}

The composite material of $\mathrm{CuAl} / \mathrm{BC}$ has been successfully prepared and applied for cationic dye adsorption. The prepared materials were characterized by XRD, FTIR, BET and SEM-EDX. The XRD and FTIR peaks have confirmed the presence of characteristics of pristine materials. The morphology of $\mathrm{CuAl} / \mathrm{BC}$ showed the heterogeneity with some aggregates from $\mathrm{LDH}$. The surface area characterization of $\mathrm{CuAl} / \mathrm{BC}$ evaluated the surface area increases four times from LDH pristine. Furthermore, $\mathrm{CuAl} / \mathrm{BC}$ composite used as an adsorbent to remove the malachite green. The parameters of adsorption were determined using kinetic, isotherm, and thermodynamic parameters. The kinetic model of pseudo-second-order was appropriate for the composites with $q_{e}$ calculation and $q_{e}$ experiment is closed. The equilibrium adsorption $\mathrm{MG}$ using $\mathrm{CuAl}$ pristine was reached at 70 minutes with $\mathrm{MG}$ adsorbed 64.8 $\mathrm{mg} / \mathrm{L}$. The equilibrium of composite was reached at 40 minutes with MG adsorbed $108.92 \mathrm{mg} / \mathrm{L}$. The isotherm adsorption follows Langmuir with maximum adsorption capacity $470.96 \mathrm{mg} / \mathrm{g}$ for composite compare to 59.523 $\mathrm{mg} / \mathrm{g}$ for pristine. The thermodynamic analysis indicates that the malachite green adsorption in $\mathrm{CuAl} \mathrm{LDH}$ and $\mathrm{CuAl} / \mathrm{BC}$ composite were spontaneous $(\Delta \mathrm{G}<0)$, endothermic $(8.634$ $\mathrm{kJ} / \mathrm{mol}$ and $7.912 \mathrm{~kJ} / \mathrm{mol}$ ), the randomness of solid-liquid phase interface $(30.702 \mathrm{~kJ} / \mathrm{mol}$ and $20.071 \mathrm{~kJ} / \mathrm{mol}$ ) and that there was a little change in the adsorbent structure after adsorption. The regeneration study showed that three cycles adsorption process would reduce the adsorption capacity for LDH significantly but not for the composite material.

\section{Acknowledgment}

Author would like to thanks to Universitas Sriwijaya, which provided funding through "Hibah Profesi Dana PNPB" in the fiscal year 2020 for supporting the financial of this research.

\section{References}

[1] Bukhtiyarova, M.V. (2019). A review on effect of synthesis conditions on the formation of layered double hydroxides. Journal of Solid State Chemistry, 269, 494-506. DOI: 10.1016/j.jssc.2018.10.018

[2] Wang, Q., Hare, D.O. (2012). Recent Advances in the Synthesis and Application of Layered Double Hydroxide (LDH) Nanosheets. Chemical Reviews, 112, 7, 4124-4155. DOI: $10.1021 / \mathrm{cr} 200434 \mathrm{v}$

[3] Mishra, G., Dash, B., Pandey, S. (2018). Layered double hydroxides: A brief review from fundamentals to application as evolving biomaterials. Appl. Clay Sci., 153, 172-186. DOI: 10.1016/j.clay.2017.12.021

[4] Antonyraj, C.A., Koilraj, P., Kannan, S. (2010). Synthesis of delaminated LDH: A facile two step approach. Chemical Communications, 46, 1902. DOI: 10.1039/b922122k

[5] Sepehr, M.N., Al-Musawi, T.J., Ghahramani, E., Kazemian, H., Zarrabi, M. (2017). Adsorption Performance of Magnesium/Aluminum Layered Double Hydroxide Nanoparticles for Metronidazole From Aqueous Solution. Arabian Journal of Chemistry, 10, 611-23. DOI: 10.1016/j.arabjc.2016.07.003

[6] Kameda, T., Takeuchi, H., Yoshioka, T. (2011). NiAl layered double hydroxides modified with citrate, malate, and tartrate: Preparation by coprecipitation and uptake of $\mathrm{Cu} 2$ from aqueous solution. Journal of Physics and Chemistry of Solids, 72, 846-51. DOI: 10.1016/j.jpcs.2011.03.003

[7] Lesbani, A., Maretha, D.R., Taher, T., Miksusanti Mohadi, R., Andreas, R. (2018). Layered double hydroxides $\mathrm{Mg} / \mathrm{Fe}$ intercalated H3[a-PW12O40] · n H2O as adsorbent of cadmium(II). AIP Conference Proceedings, 2049, 020013. DOI: 10.1063/1.5082418

[8] Sun, X., Dong, J., Li, Z., Liu, H., Jing, X., Chi, Y., Hu, C. (2019). Mono-transition-metalsubstituted polyoxometalate intercalated layered double hydroxides for the catalytic decontamination of sulfur mustard simulant. Dalton Transactions, 48, 5285-5291. DOI: 10.1039/c9dt00395a

[9] Fu, F., Wang, Q. (2011). Removal of heavy metal ions from wastewaters: A review. Journal of Environmental Management, 92, 407418. DOI: 10.1016/j.jenvman.2010.11.011 
[10] Oktriyanti, M., Palapa, N.R., Mohadi, R., Lesbani, A. (2019). Modification Of Zn-Cr Layered Double Hydroxide With Keggin Ion. Indonesian Journal of Environmental Management and Sustainability, 3, 93-99.

[11] Zhu, J., He, J., Du, X., Lu, R., Huang, L., Ge, X. (2011). A facile and flexible process of Bcyclodextrin grafted on $\mathrm{Fe} 3 \mathrm{O} 4$ magnetic nanoparticles and host-guest inclusion studies. Applied Surface Science, 257, 9056-9062. DOI: 10.1016/j.apsusc.2011.05.099

[12] Qu, J., Sha, L., Wu, C., Zhang, Q. (2019). Applications of mechanochemically prepared layered double hydroxides as adsorbents and catalysts: A mini-review. Nanomaterials, 9, 115. DOI: $10.3390 /$ nano9010080

[13] Zoromba, M.S., Nour, M.A., Eltamimy, H.E., Abd El-Maksoud, S.A. (2018). Effect of modified layered double hydroxide on the flammability and mechanical properties of polypropylene. Science and Engineering of Composite Materials, 25, 101-108. DOI: 10.1515/secm2016-0050

[14] Ruan, X., Chen, Y., Chen, H., Qian, G., Frost, R.L. (2016). Sorption behavior of methyl orange from aqueous solution on organic matter and reduced graphene oxides modified $\mathrm{Ni}-\mathrm{Cr}$ layered double hydroxides. Chemical Engineering Journal, 297, 295-303. DOI: 10.1016/j.cej.2016.01.041

[15] Leng, L., Yuan, X., Zeng, G., Shao, J., Chen, X., Wu, Z., Wang, H., Peng, X. (2015). Surface characterization of rice husk bio-char produced by liquefaction and application for cationic dye (Malachite green) adsorption. Fuel, 155, 77-85. DOI: 10.1016/j.fuel.2015.04.019

[16] Huang, D., Liu, C., Zhang, C., Deng, R., Wang, R., Xue, W., Luo, H., Zeng, G., Zhang, Q., Guo, X. (2019). Cr(VI) removal from aqueous solution using biochar modified with $\mathrm{Mg} / \mathrm{Al}$-layered double hydroxide intercalated with ethylenediaminetetraacetic acid. Bioresource Technology, 276, 127-132. DOI: 10.1016/j.biortech.2018.12.114

[17] Xu, X., Cao, X., Zhao, L. (2013). Comparison of rice husk- and dairy manure-derived biochars for simultaneously removing heavy metals from aqueous solutions: Role of mineral components in biochars. Chemosphere, 92,

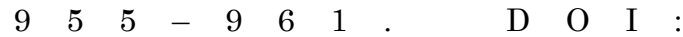
10.1016/j.chemosphere.2013.03.009

[18] Tareq, R., Akter, N., Azam, M.S. (2019). Biochars and Biochar Composites [Internet]. Biochar from Biomass Waste. Elsevier Inc. DOI: 10.1016/b978-0-12-811729-3.00010-8

[19] Meili, L., Lins, P.V., Zanta, C.L.P.S., Soletti, J.I., Ribeiro, L.M.O., Dornelas, C.B., Silva, T.L., Vieira, M.G.A. (2019). MgAlLDH/Biochar composites for methylene blue removal by adsorption. Applied Clay Science, 168, 11-20. DOI: 10.1016/j.clay.2018.10.012

[20] Wan, S., Wang, S., Li, Y., Gao, B. (2017). Functionalizing biochar with $\mathrm{Mg}-\mathrm{Al}$ and $\mathrm{Mg}-$ Fe layered double hydroxides for removal of phosphate from aqueous solutions. Journal of Industrial and Engineering Chemistry, 47, 246-253. DOI: 10.1016/j.jiec.2016.11.039

[21] Wang, S., Gao, B., Li, Y., Zimmerman, A.R., Cao, X. (2016). Sorption of arsenic onto Ni/Fe layered double hydroxide (LDH)-biochar composites. RSC Advances, 6, 17792-17799. DOI: 10.1039/c5ra17490b

[22] Li, H., Wen, J., Yu, R., Meng, J., Wang, C., Wang, C., Sun, S. (2015). Facile synthesis of a nanocomposite based on graphene and $\mathrm{ZnAl}$ layered double hydroxides as a portable shelf of a luminescent sensor for DNA. RSC Advances, 5, 9341-9247. DOI: 10.1039/C4RA15395B

[23] Palapa, N.R., Mohadi, R., Rachmat, A., Lesbani, A. (2020). Adsorption Study of Malachite Green Removal from Aqueous Solution Using $\mathrm{Cu} / \mathrm{M}^{3+}\left(\mathrm{M}^{3+}=\mathrm{Al}, \mathrm{Cr}\right.$ ) Layered Double Hydroxide. Mediterranean Journal of Chemistry, 10, 33-45.

[24] Zubair, M., Jarrah, N., Khalid, A., Saood, M. (2018). Starch-NiFe-layered double hydroxide composites: Efficient removal of methyl orange from aqueous phase. Journal of Molecular Liquids, 249, 254-264. DOI: 10.1016/j.molliq.2017.11.022

[25] Szabados, M., Kónya, Z., Kukovecz, Á., Sipos, P., Pálinkó, I. (2019). Structural reconstruction of mechanochemically disordered CaFelayered double hydroxide. Applied Clay Science, $174, \quad 138-145$. D O I : 10.1016/j.clay.2019.03.033

[26] Benito, P., Herrero, M., Labajos, F.M., Rives, V. (2010). Effect of post-synthesis microwave - hydrothermal treatment on the properties of layered double hydroxides and related materials. Applied Clay Science, 48, 218-227. DOI: 10.1016/j.clay.2009.11.051

[27] Wang, N., Sun, J., Fan, H., Ai, S. (2016). Anion-intercalated layered double hydroxides modified test strips for detection of heavy metal ions. Talanta, 148, 301-307. DOI: 10.1016/j.talanta.2015.11.007

[28] Sun, X., Neuperger, E., Dey, S.K. (2015). Insights into the synthesis of layered double hydroxide (LDH) nanoparticles: Part 1. Optimization and controlled synthesis of chlorideintercalated LDH. Journal of Colloid and Interface Science, 459, 264-272. DOI: 10.1016/j.jcis.2015.07.073

[29] Gunawan, P., Xu, R. (2009). Direct assembly of anisotropic layered double hydroxide $(\mathrm{LDH})$ nanocrystals on spherical template for 
fabrication of drug-LDH hollow nanospheres. Chemistry of Materials, 21(5), 781783.

[30] Pang, X., Chen, L., Liu, Y., Chi, M., Li, Z., Plank, J. (2017). Growth behavior of water dispersed $\mathrm{MgAl}$ layered double hydroxide nanosheets. RSC Advances, 7, 14989-97. DOI: $10.1039 / \mathrm{C} 7 \mathrm{RA00833C}$

[31] Zhang, Q., Jiao, Q., Leroux, F., Tang, P., Li, D., Feng, Y. (2017). Antioxidant intercalated hydrocalumite as multifunction nanofiller for Poly(propylene): Synthesis, thermal stability, light stability, and anti-migration property. Polymer Degradation and Stability, 140, 9-16. DOI: 10.1016/j.polymdegradstab.2017.04.012

[32] Parida, K.M., Mohapatra, L. (2012). Carbonate intercalated $\mathrm{Zn} / \mathrm{Fe}$ layered double hydroxide: A novel photocatalyst for the enhanced photo degradation of azo dyes. Chemical Engineering Journal, 179, 131-139. DOI: 10.1016/j.cej.2011.10.070

[33] Zhao, S., Xu, J., Wei, M., Song, Y.F. (2011). Synergistic catalysis by polyoxometalateintercalated layered double hydroxides: Oximation of aromatic aldehydes with large enhancement of selectivity. Green Chemistry, 13, 384-389. DOI: 10.1039/c0gc00664e

[34] Darmograi, G., Prelot, B., Geneste, A., Martin-Gassin, A., Salles, F., Zajac, J. (2016). How does competition between anionic pollutants affect adsorption onto $\mathrm{Mg}$-Al layered double hydroxide? Three competition schemes. Journal of Physical Chemistry $C$, $120, \quad 10410-10418$. D O I : 10.1021/acs.jpcc.6b01888

[35] Daud, M., Hai, A., Banat, F., Wazir, M.B., Habib, M., Bharath, G., Al-Harthi, M.A. (2019). A review on the recent advances, challenges and future aspect of layered double hydroxides (LDH) - Containing hybrids as promising adsorbents for dyes removal. Journal of Molecular Liquids, 288, 110989. DOI: 10.1016/j.molliq.2019.110989

[36] George, G., Saravanakumar, M.P. (2018). Facile synthesis of carbon-coated layered double hydroxide and its comparative characterisation with $\mathrm{Zn}-\mathrm{Al} \mathrm{LDH}$ : application on crystal violet and malachite green dye adsorptionisotherm, kinetics and Box-Behnken design. Environmental Science and Pollution Research International, 25, 30236-30254. DOI: 10.1007/s11356-018-3001-3

[37] Islam, M.A., Ali, I., Karim, S.M.A., Hossain Firoz, M.S., Chowdhury, A.N., Morton, D.W., Angove, M.J. (2019). Removal of dye from polluted water using novel nano manganese oxide-based materials. Journal of Water Process Engineering, 32, 100911 . DOI: 10.1016/j.jwpe.2019.100911
[38] Yu, S., Wang, X., Chen, Z., Wang, J., Wang, S., Hayat, T., Wang, X. (2017). Layered double hydroxide intercalated with aromatic acid anions for the efficient capture of aniline from aqueous solution. Journal of Hazardous Materials, $321, \quad 111-120$. D O : 10.1016/j.jhazmat.2016.09.009

[39] Lu, Y., Jiang, B., Fang, L., Ling, F., Gao, J., Wu, F., Zhang, X. (2016). High performance $\mathrm{NiFe}$ layered double hydroxide for methyl orange dye and $\mathrm{Cr}(\mathrm{VI})$ adsorption. Chemosphere, $152, \quad 415-422$. DOI : 10.1016/j.chemosphere.2016.03.015

[40] Nishimura, S., Takagaki, A., Ebitani, K. (2010). Monodisperse iron oxide nanoparticles embedded in $\mathrm{Mg}$-Al hydrotalcite as a highly active, magnetically separable, and recyclable solid base catalyst. Bulletin of the Chemical Society of Japan, 83, 846-851. DOI: 10.1246/bcsj.20100059

[41] Lesbani, A., Tarmizi, R. D., Taher, T., Palapa, N. R., Mohadi, R. (2019). Preparation of Ni-Al LDH: Influence of intercalated polyoxometalate anion $\left(\alpha-\mathrm{SiW}_{12} \mathrm{O}_{40}\right)$ 4-on the interlayer gallery distance. AIP Conference Proceedings, 2194 (1), 020054. AIP Publishing

[42] Vyavahare, G.D., Gurav, R.G., Jadhav, P.P., Patil, R.R., Aware, C.B., Jadhav, J.P. (2018). Response surface methodology optimization for sorption of malachite green dye on sugarcane bagasse biochar and evaluating the residual dye for phyto and cytogenotoxicity. Chemosphere, 194, 306-315. DOI: 10.1016/j.chemosphere.2017.11.180

[43] Saha, P., Chowdhury, S., Gupta, S., Kumar, I. (2010). Insight into adsorption equilibrium, kinetics and thermodynamics of Malachite Green onto clayey soil of Indian origin. Chemical Engineering Journal, 165, 874-882. DOI: 10.1016/j.cej.2010.10.048

[44] Ahmad, M.A., Afandi, N.S., Bello, O.S. (2017). Optimization of process variables by response surface methodology for malachite green dye removal using lime peel activated carbon. Applied Water Science, 7, 717-727. DOI: 10.1007/s13201-015-0284-0

[45] Beakou, B.H., El Hassani, K., Houssaini, M.A., Belbahloul, M., Oukani, E., Anouar, A. (2017). A novel biochar from Manihot esculenta Crantz waste: Application for the removal of Malachite Green from wastewater and optimization of the adsorption process. Water Science and Technology, 76, 1447-56. DOI: $10.2166 /$ wst.2017.332

[46] Zhang, J., Liu, M., Yang, T., Yang, K., Wang, H. (2016). A novel magnetic biochar from sewage sludge: Synthesis and its application for the removal of malachite green from wastewater. Water Science and Technology, 74, 1971-1979. DOI: 10.2166/wst.2016.386 
[47] Kulaksiz, E., Gözmen, B., Kayan, B., Kalderis, D. (2017). Adsorption of Malachite Green on Fe-modified biochar: Influencing factors and process optimization. Desalination and Water Treatment, 74, 383-394. DOI: 10.5004/dwt.2017.20601
[48] Das, S., Dash, S.K., Parida, K.M. (2018). Kinetics, Isotherm, and Thermodynamic Study for Ultrafast Adsorption of Azo Dye by an Efficient Sorbent: Ternary $\mathrm{Mg} /(\mathrm{Al}+\mathrm{Fe})$ Layered Double Hydroxides. ACS Omega, 3, 25322545. DOI: 10.1021/acsomega.7b01807 